\title{
JUKMAS
}

Jurnal Untuk Masyarakat Sehat (JUKMAS)

e-ISSN : 2715-7687

Vol. 5, No. 1 April 2021

P-ISSN : 2715-8748

\section{Komposisi Lemak Viseral, Basal Metabolic Rate (BMR), Dan Usia Sel Terhadap Indeks Masa Tubuh (IMT) Pada Remaja}

\author{
Munawaroh, Wiwit Wijayanti, Okta Zenita Siti Fatimah \\ Prodi Kebidanan Fakultas Kesehatan Universitas MH. Thamrin \\ Email : muna.munawaroh28@gmail.com,fara2708@gmail.com, okta.zenita@gmail.com
}

\begin{abstract}
Abstrak
Status gizi remaja dapat dihitung berdasarkan Indeks Masa Tubuh (IMT). Remaja yang mengkonsumsi makanan yang tinggi kalori dan rendah serat dapat menyebabkan ketidakseimbangan antara asupan dan luaran energi sehingga menyebabkan meningkatnya berat badan.. Proporsi overweight usia > 18 tahun terus mengalami peningkatan sejak tahun 2007, 2013 dan 2018 yaitu 8.6\% 11.5\% dan 13.6\%. Penelitian ini bertujuan untuk mengetahui gambaran Indeks Massa Tubuh (IMT) dan hubungannya terhadap Basal Metabolic Rate, lemak viseral dan usia sel pada kelompok remaja dengan menggunakan alat Bioimpedency Analisys (BIA). Metode penelitian kuantitatif dengan pendekatan cross sectional dengan sampel lulusan SMU yang mendaftar ke Universitas $\mathrm{MH}$. Thamrin berjumlah 42 responden yang diambil secara Accidental Sampling. Hasil penelitian berdasarkan Indeks Masa Tubuh (IMT) adalah 61.9\% kategori normal sedangkan 21,4\% mengalami overweight dan 16,7 \% underweight, rata-rata BMR dari responden adalah $1384 \mathrm{Kkal}(95 \% \mathrm{Cl} 1312.2-1456.5)$ dengan Standar Deviasi 231,5 serta $61.9 \%$ memiliki lemak viseral normal dan 38.1\% memiliki lemak viseral tidak normal, $78.6 \%$ memiliki usia sel lebih muda/sesuai usia kronologisnya dan $21.4 \%$ memiliki usia sel lebih tua dari usia kronologisnya. Remaja overweight dengan usia sel lebih tua dari usia kronologisnya dapat dilakukan skrining untuk menerapkan modifikasi perilaku dan gaya hidup sehat.
\end{abstract}

Kata kunci : IMT, Lemak Viseral, usia sel

\begin{abstract}
The nutritional status of adolescents can be calculated based on the Body Mass Index (BMI). Adolescents who consume foods that are high in calories and low in fiber can cause an imbalance between energy intake and output, leading to weight gain. The proportion of overweight aged $>18$ years has continued to increase since 2007, 2013 and 2018, namely $8.6 \% 11.5 \%$ and $13.6 \%$. This study aims to determine the description of Body Mass Index (BMI) and its relationship to Basal Metabolic Rate, visceral fat and cell age in the adolescent group using the Bioimpedency Analysis (BIA) tool. Quantitative research method with cross sectional approach with a sample of high school graduates who enrolled in $\mathrm{MH}$ University. Thamrin amounted to 42 respondents who were taken by accidental sampling. The results of the study based on the Body Mass Index (BMI) were $61.9 \%$ in the normal category while $21.4 \%$ were overweight and $16.7 \%$ were underweight, the average BMR of the respondents was $1384 \mathrm{Kcal}$ (95\% Cl 1312.2-1456.5) with Standard Deviation of 231, 5 and $61.9 \%$ had normal visceral fat and $38.1 \%$ had abnormal visceral fat, $78.6 \%$ had younger cell age / according to chronological age and $21.4 \%$ had cell age older than chronological age. Overweight adolescents with cell ages older than chronological age can be screened for behavior modification and healthy lifestyle.
\end{abstract}

Key words : BMI, Viseral Fat, cell age

http://ejournal.urindo.ac.id/index.php/jukmas

Article History :

Submitted 30 Desember 2020, Accepted 28 April 2021, Published 30 April 2021 


\section{PENDAHULUAN}

Permasalahan gizi erat hubungannya terhadap gangguan kesehatan seseorang, kelompok dan masyarakat. Adanya ketidakseimbangan antara asupan (intake) dengan kebutuhan tubuh yang berakibat gizi kurang ataupun gizi lebih. Kemajuan dan perkembangan di bidang teknologi, pendidikan dan transportasi memberikan kemudahan bagi manusia pada umumnya. Kemudahan tersebut membawa perubahan prilaku seseorang dalam mencari makanan yang serba cepat dan instan untuk menghemat waktu dan aktivitas dalam kehidupan sehari-hari. Orang cenderung memilih aktivitas yang lebih cepat dari pada yang lebih lama, seperti mengendarai kendaraan untuk menuju ke suatu tempat. ${ }^{8}$

Fase pertumbuhan yang cepat terjadi pada remaja, sehingga memerlukan zat gizi yang lebih besar jumlahnya. Gaya hidup dan kebiasaan makan remaja yang berubah mempengaruhi asupan energi dan zat gizi. Hal ini menyebabkan pola makan yang berlebih, makan rendah serat yang menyebebkan obesitas atau sebaliknya remaja membatasi makan karena mementingkan penampilan fisik sehingga mengalami kekurangan gizi. ${ }^{14}$

Status gizi remaja dapat dihitung berdasarkan Indeks Masa Tubuh (IMT), prevalensi remaja 13-18 tahun yang termasuk kategori gemuk sebanyak 1,4\%

sementara itu prevalensi obesitas (IMT>25) pada laki-laki $19,7 \%$ dan pada perempuan sebanyak $32,9 \% .{ }^{10}$

Proporsi BB lebih (overweight) pada usia > 18 tahun terus mengalami peningkatan yaitu $8.6 \%$ (2007), 11.5\% (2013) dan $13.6 \%$ (2018). Proporsi obesitas sentral pada usia $>15$ tahun juga mengalami peningkatan yaitu,
$18.8 \%$ (2007), $26.6 \%$ (2013) dan 31.0\% $(2018)^{10}$

Penelitian lain tentang hubungan berat badan, persen lemak tubuh, status gizi (IMT/U), umur menarche ibu dengan umur menarche pada siswa di SDN Cikaret 01 Cibinong Bogor bahwa ada hubungan antara persen lemak tubuh dan status gizi dengan usia menarche. ${ }^{14}$

Hubungan Indeks Massa Tubuh, persen lemak tubuh, aktivitas fisik dan faktor lainnya dengan obesitas sentral pada pegawai Satlantas dan SUMDA menyatakan bahwa ada hubungan antara (Indek Masa Tubuh (IMT), persen lemak tubuh dan aktivitas fisik dengan terjadinya obesitas sentral. $^{2}$

Ditemukan bahwa IMT remaja sebanyak 23,8\% remaja termasuk overweight, 5,9\% obesitas dan 5,9 underweight (kurus). Sedangkan untuk persen lemak tubuh menunjukkan sebanyak $8,9 \%$ remaja underfat, sebanyak $12,9 \%$ overfat dan $12,9 \%$ obesitas. $^{10}$

Basal Metabolic Rate (BMR) atau Angka Metabolisme Basal (AMB) merupakan kebutuhan energi minimal yang diperlukan untuk proses tubuh vital. Proses tubuh vital meliputi mempertahankan tonus otot, sistem

peredaran darah, pernapasan, metabolisme sel, dan mempertahankan suhu tubuh. Beberapa faktor yang

mempengaruhi BMR, yaitu: jenis kelamin, umur, berat badan, komposisi

tubuh, derajat kesehatan, suhu lingkungan, suhu tubuh, aktivitas, sekresi hormon, status gizi, kebiasaan merokok, dan keadaan hamil dan menyusui. Salah satu cara menghitung BMR adalah berdasarkan berat badan dan jenis kelamin. Untuk BMR laki-laki 
$=$ BB kg x $1.0 \mathrm{kkal}$ x 24 jam. Sedangkan untuk $B M R$ perempuan $=B B \mathrm{~kg} \times 0.9 \mathrm{kkal}$ $\times 24$ jam. ${ }^{9}$

Basal Metabolic Rate (BMR) berbanding lurus dengan massa tubuh tanpa lemak, semakin banyak massa tubuh tanpa lemak yang dimiliki seseorang semakin tinggi BMR-nya. Namun BMR juga dipengaruhi oleh penyakit akut dan meningkat dengan kondisi seperti luka bakar, patah tulang infeksi, demam dan lain-lain. ${ }^{5}$

Lemak visceral atau lemak organ (intraabdominal) adalah lemak yang disimpan dalam jaringan adiposa bagian perut (area rongga perut). Lemak viseral yang terakumulasi menempel pada organ-organ vital di dalam rongga perut. Lemak yang disimpan dalam jaringan adiposa (kumpulan sel adiposit atau jaringan yang berfungsi untuk menimbun lemak) biasanya berwujud sebagai trigliserida. Penumpukan lemak viseral yang tinggi dapat menimbulkan obesitas sentral dan sindrom metabolik sebagai resiko terjadinya penyakit degeneratif. ${ }^{19}$

Dalam penelitiannya yang berjudul Upaya Preventif Penyakit Degeneratif Melalui Pemeriksaan Lemak Viseral Masyarakat Di Wilayah Pesantren Asshiddiqiyah Jakarta Barat 2017 mendapatkan hasil bahwa lemak visceral berskala 9-14 termasuk kategori lemak visceral tinggi. ${ }^{20}$

Kebiasaan masyarakat tidak berolahraga dan konsumsi tinggi kalori menjadi penyebab hal ini terjadi. ${ }^{21}$

Usia biologis dapat berbeda dengan usia kronologis yang seharusnya sama karena disebabkan oleh beberapa faktor. Usia biologis adalah kondisi sel/jaringan tubuh seseorang sehingga bisa jadi lebih muda atau lebih tua dari usia kronologisnya. Penurunan usia biologis dapat disebabkan oleh faktor genetika, faktor endogenik dan lingkungan. ${ }^{6}$

Umum ada dua pengertian tentang usia yaitu:

a. Usia kronologis yaitu lama hidup seseorang sejak tanggal, bulan, dan tahun ia dilahirkan yang dinyatakan dalam angka-angka.

b. Usia biologis yaitu usia yang diukur dari keadaan jaringan tubuh seperti elastisitas dari jaringan kolagen yang mana kondisi ini dipengaruhi oleh lingkungan, gizi dll. ${ }^{11}$

Dalam penelitian tentang Faktor yang menyebabkan perbedaan usia biologis dan usia kronologis pada lansia di dapatkan hasil bahwa terdapat asosiasi bermakna $(p=0.012)$ antara usia biologis dan indeks massa tubuh. Namun tidak terdapat asosiasi bermakna antara usia biologis dan lemak visceral $(p=0.478)^{6}$

Tujuan penelitian ini adalah untuk mengetahui gambaran Indeks Massa Tubuh (IMT) dan hubungannya terhadap Basal Metabolisme Rate, lemak viceral dan usia sel pada remaja

\section{METODE}

Desain penelitian ini menggunakan pendekatan deskriptif kuantitatif, dengan menggunakan desain Crossectional yang mana akan dilakukan pengukuran Indeks Massa Tubuh (IMT), Basal Metabolic Rate $(B M R)$,lemak visceral dan usia sel dalam waktu yang bersamaan. Sampel dalam penelitian ini adalah putra putri lulusan SMU/sederajat yang datang ke Universitas $\mathrm{MH}$. Thamrin untuk mendaftarkan diri sebagai calon mahasiswa baru ataupun hanya mencari informasi yang datang selama Agustus-September 2020 sebanyak 42 responden. Sampel diambil secara accidental dikarenakan kondisi pandemi Covid-19 sehingga banyak calon mahasiswa yang mendaftar secara online. Responden yang bersedia diinformasikan tentang naskah penjelasan dan menandatangani formulir persetujuan setelah penjelasan, kemudian dilakukan pengukuran dengan alat Impedence Bioanalysis (BIA). 
Pengukuran yang dilakukan meliputi Indeks Massa Tubuh (IMT), Berat Badan, usia Kronologis, Basal Metabolisme Rate (BMR), persentase lemak viseral dan usia sel.

Analisis data dilakukan dengan menggunakan uji Chi-Square dan uji $T$ sehingga dapat mengetahui hubungan antara IMT dengan BMR, IMT dengan lemak visceral serta IMT dengan usia sel. Analisi IMT terhadap BMR dilakukan dengan menggunakan uji $T$ sedangkan analisis IMT terhadap lemak viseral dan usia sel

Tabel 1

Distribusi Responden Berdasarkan Umur

\begin{tabular}{ccc}
\hline Umur & Jumlah & $\%$ \\
\hline 18 tahun & 8 & 19.0 \\
19 tahun & 6 & 14.3 \\
20 tahun & 9 & 21.4 \\
21 tahun & 12 & 28.6 \\
22 tahun & 4 & 9.5 \\
23 tahun & 3 & 7.1 \\
& & \\
\hline
\end{tabular}

Tabel 2

Distribusi Responden Berdasarkan Jenis kelamin

\begin{tabular}{ccc}
\hline Jenis Kelamin & Jumlah & $\%$ \\
\hline Laki-laki & 9 & 21.4 \\
Perempuan & 33 & 78.6 \\
\hline & 42 & 100 \\
\hline
\end{tabular}

Tabel 3 menyatakan bahwa distribusi responden berdasarkan Indeks Masa Tubuh (IMT) terbesar adalah 26 responden (61.9\%) dalam kategori IMT normal (18.5-25), 9 responden $(21.4 \%)$ dalam kategori gemuk dan 7 responden (16.7\%) dalam kurus. Distribusi responden berdasarkan persentase lemak viseral adalah 26 responden (61.9\%) memiliki persentase lemak visceral normal, sedangkan 16 responden ( $38.1 \%)$ memiliki persentase dilakukan dengan menggunakan uji ChiSquare.

\section{HASIL DAN PEMBAHASAN}

Tabel 1 menyatakan bahwa distribusi responden berdasarkan usia terbesar adalah 12 responden (28.6\%) berusia 21 tahun dan yang terkecil adalah 3 responden (7.1\%) berusia 23 tahun. Tabel 2 menyatakan bahwa distribusi responden berdasarkan jenis kelamin adalah 33 rsponden (78.6\%) perempuan dan 9 responden (21.4\%) lakilaki. 
Jurnal Untuk Masyarakat Sehat (JUKMAS)

Tabel 3

Ditribusi Responden Berdasarkan Indeks Massa Tubuh (IMT)

\begin{tabular}{cccc}
\hline & Variabel & Jumlah & $\%$ \\
\hline \multirow{2}{*}{ IMT } & $\leq 18.4$ (kurus) & 7 & 16.7 \\
& $18.5-25$ (normal) & 26 & 61.9 \\
& $\geq 25.1$ (gemuk) & 9 & 21.4 \\
\hline Lemak viseral & $\leq 3$ (normal) & 26 & 61.9 \\
& $>3$ (berlebih) & 16 & 38.1 \\
\hline Usia sel & $\leq$ usia & 33 & 78.6 \\
& $>$ usia & 9 & 21.4 \\
\hline
\end{tabular}

Tabel 4

Distribusi Responden Berdasarkan Basal Matabolisme Rate (BMR)

\begin{tabular}{ccccc}
\hline Variabel & Mean & SD & Minimal-maksimal & 95\% Cl \\
\hline BMR & 1384 & 231,541 & $1078-2047$ & $1312.23-1456.53$ \\
\hline
\end{tabular}

Berdasarkan tabel 5 dan 6 menyatakan bahwa rata-rata BMR dengan IMT normal adalah 1349.42 dengan standar deviasi 193.386 sedangkan rata-rata BMR dengan IMT tidak normal adalah 1441.19 dengan standar deviasi 280.442 . Dengan $p$ value 0.216 pada alpha $5 \%$ artinya tidak ada perbedaan yang signifikan rata-rata BMR antara responden dengan IMT normal

dengan yang tidak normal. Berdasarkan tabel 6 menyatakan

bahwa distribusi responden berdasarkan lemak viseral dengan IMT diperoleh bahwa ada sebanyak 19 (73.1\%) responden dengan lemak visceral lebih dari sama dengan 3 memiliki IMT normal sedangkan 7

Tabel 5

Distribusi Responden Berdasarkan IMT dan BMR
(43.8\%) responden memiliki lemak viseral lebih dari 3 memiliki IMT normal. Dengan value 0.116 dan alpha 5\% maka tidak ada hubungan antara IMT dengan lemak visceral. Distribusi responden berdasarkan usia sel dengan IMT diperoleh bahwa ada

sebanyak 26 (78.8\%) responden dengan usia sel lebih muda atau sama dengan usia kronologisnya memiliki IMT normal dan 2 (22.2\%) responden memiliki usia sel lebih tua dari usia kronologis dengan IMT normal. Pada $\mathrm{P}$ value 0.00 dan alpha 5\% maka dapat disimpulkan bahwa ada perbedaan antara IMT normal dan IMT tidak normal terhadap usia sel responden. 


\begin{tabular}{cccccc}
\hline IMT & Mean & SD & SE & P Value & N \\
\hline Normal & 1349.42 & 193.386 & 37.926 & 0.216 & 26 \\
Tidak & 1441.19 & 280.442 & 70.110 & & 16 \\
\hline
\end{tabular}

Tabel 6

Distribusi Responden Berdasarkan IMT, lemak viseral, usia sel

\begin{tabular}{|c|c|c|c|c|c|c|c|c|c|}
\hline \multirow{2}{*}{\multicolumn{2}{|c|}{ Variabel }} & \multicolumn{4}{|c|}{ IMT } & \multirow{2}{*}{\multicolumn{2}{|c|}{ Total }} & \multirow{3}{*}{$\begin{array}{c}\text { OR } \\
95 \% \mathrm{Cl}\end{array}$} & \multirow[t]{3}{*}{ P Value } \\
\hline & & \multicolumn{2}{|c|}{ Normal } & \multicolumn{2}{|c|}{ Tidak } & & & & \\
\hline & & $\mathbf{N}$ & $\%$ & $\mathbf{N}$ & $\%$ & $n$ & $\%$ & & \\
\hline \multirow[t]{2}{*}{ Lemak Viceral } & $\leq 3$ (normal) & 19 & 73.1 & 7 & 26.9 & 26 & 100 & 3.490 & 0.116 \\
\hline & $>3$ (tidak) & 7 & 43.8 & 9 & 56.3 & 16 & 100 & & \\
\hline \multirow[t]{2}{*}{ Usia sel } & $\leq$ usia kronologis & 26 & 78.8 & 7 & 21.2 & 33 & 100 & 1.435 & 0.00 \\
\hline & > usia kronologis & 2 & 22,2 & 7 & 77,8 & 9 & 100 & & \\
\hline
\end{tabular}

Indeks Massa Tubuh (IMT) adalah ukuran yang digunakan untuk mengetahui status gizi seseorang yang didapat dari perbandingan berat badan dan tinggi badan. Adapun cara menghitung Indeks Masa Tubuh (IMT) adalah dengan membagi berat badan (dalam kilogram) dengan tinggi badan (dalam meter kuadrat).

IMT responden dikategorikan menurut Kemenkes RI yaitu kurus $(<18,4)$, Normal (18,5 - 25), dan gemuk (>25.1). Hasil penelitian didapatkan hasil Indeks Masa Tubuh (IMT) terbesar adalah 26 responden (61.9\%) dalam kategori normal

(18.5-25). Sedangkan 21,4\% gemuk dan $16,7 \%$ masuk dalam kelompok kurus. Hal ini sejalan dengan Hasil penelitian tentang Hubungan Aktifitas Fisik dengan IMT dan Komposisi Tubuh bahwa $64,6 \%$ responden memiliki IMT normal , underweight $13.8 \%$ dan Obesitas $13.8 \%$. $^{18}$

Basal Metabolic Rate (BMR) atau Angka Metabolisme Basal (AMB) adalah energi minimal yang dibutuhkan untuk melakukan proses tubuh vital. Proses tubuh vital meliputi mempertahankan tonus otot, sistem peredaran darah, pernapasan, metabolisme sel, dan mempertahankan suhu tubuh. Faktor-faktor yang mempengaruhi BMR, antara lain jenis kelamin, umur, ukuran tubuh (berat badan), komposisi tubuh, tingkat kesehatan, suhu lingkungan, suhu tubuh, aktivitas, sekresi hormon, status gizi, kebiasaan merokok, dan keadaan hamil dan menyusui. Tubuh menghasilkan energi karena adanya pembakaran karbohidrat, protein, dan lemak sehingga manusia memerlukan makanan yang cukup bagi tubuhnya. ${ }^{12}$ Energi dapat diukur dalam joule atau kalori. Energi seseorang dalam sehari ditaksir dari kebutuhan energi dari beberapa komponen seperti angka metabolisme dasar (BMR), aktifitas fisik dan pengaruh dinamik khusus

makanan. Berdasarkan hasil penelitian menyatakan bahwa rata-rata Basal Metabolic Rate (BMR) dari responden adalah $1384 \mathrm{Kkal}(95 \% \mathrm{Cl} \quad 1312,2-$ 1456,5) BMR dengan IMT normal adalah 1349.4 dengan standar deviasi 193.386 
sedangkan BMR dengan IMT tidak normal adalah 1441.19 dengan standar deviasi 280.442. Dengan $p$ value 0.216 pada alpha $5 \%$ artinya tidak ada perbedaan yang signifikan rata-rata BMR antara responden dengan IMT normal dengan yang tidak normal.

Teori menyatakan bahwa BMR dipengaruhi oleh jenis kelamin, umur, ukuran tubuh (berat badan), komposisi tubuh, tingkat kesehatan, suhu lingkungan, suhu tubuh, aktivitas, sekresi hormon, status gizi, kebiasaan merokok, dan keadaan hamil serta menyusui. Jadi seseorang dapat mengontrol berat badannya dengan cara mengetahui IMT dan BMR. Dengan mengetahui BMR seseorang dapat mengetahui berapa jumlah kalori yang dibutuhkan dalam makanan per harinya. Untuk menurunkan berat badan dapat dilakukan dengan cara mengurangi 300 kalori dari total kalori harian.

Basal Metabolisme Rate (BMR) berbanding lurus dengan massa tubuh tanpa lemak, semakin banyak massa tubuh tanpa lemak yang dimiliki seseorang semakin tinggi BMR-nya. Namun BMR juga dipengaruhi oleh penyakit akut dan meningkat dengan kondisi seperti luka bakar, patah tulang infeksi, demam dan lain-lain. ${ }^{4}$

Tubuh manusia tersusun atas massa lemak (Fat Mass) dan massa non lemak (Free Fat Mass). ${ }^{16}$ Umumnya massa lemak tersebar secara luas lebih dari $50 \%$ tersimpan dalam jaringan subkutan, sebagian lainnya tersimpan dirongga abdomen sebesar $45 \%$ yang disebut lemak visceral dan sebanyak $5 \%$ terdapat dijaringan intramuskular. ${ }^{7}$
Sementara lemak viseral adalah lemak yang tertumpuk di daerah perut (intraabdominal fat) sehingga menyebabkan obesitas sentral. ${ }^{20}$

Hasil penelitian menunjukan bahwa distribusi responden berdasarkan

lemak viseral dengan IMT diperoleh bahwa ada sebanyak 19 (73.1\%) responden dengan lemak visceral normal $(\geq 3)$ memiliki IMT normal dan 7 responden (26.9\%) memiliki IMT tidak normal, sedangkan 7 (43.8\%) responden dengan lemak visceral tidak normal/berlebih $(<3)$ memiliki IMT normal dan 9 responden (56.3\%) memiliki IMT tidak normal. Pada P value 0.116 maka dapat disimpulkan bahwa tidak ada perbedaan antara IMT normal dan tidak normal terhadap lemak viseral.

Hal ini sejalan dengan penelitian Sofa tentang kejadian obesitas, obesitas sentral dan kelebihan lemak visceral pada lansia wanita bahwa ada hubungan antara obesitas dengan lemak viseral namun tidak ada hubungan antara usia dengan lemak viseral. ${ }^{18}$

Hal ini tidak sejalan dengan penelitian Pradana tentang Hubungan Antara Indeks Massa Tubuh (IMT) dengan Nilai Lemak Viseral (Studi kasus pada mahasiswa kedokteran UNDIP) didapatkan hasil bahwa ada korelasi positif antara IMT dengan lemak viseral pada mahasiswa kedokteran Undip dengan $p=0.005$ dan $r=0.912 .{ }^{14}$

Aulia, $\mathrm{R}$ tentang Hubungan Indeks Massa Tubuh dan Aktivitas Fisik terhadap Massa Lemak Viseral dan Massa Lemak Total pada Mahasiswa Universitas Bengkulu Tahun 2016 Mendapatkan hasil bahwa terdapat hubungan signifikan antara IMT terhadap massa lemak viseral ( $p=0.000 ; r=0.612 ; r=0.637)$. sementara IMT terhadap massa lemak total berhubungan signifikan dengan 
$p=0.000 ; r=0.612 ; r=3.43) . \quad$ Teor menyatakan bahwa lemak viseral adalah salah satu komponen dalam tubuh manusia yang dapat mempengaruhi berat badan. IMT merupakan indikator yang menunjukkan status gizi seseorang yang diperoleh dari perhitungan antara tinggi badan dan berat badan, sehingga lemak viseral sebagai komponen tubuh dapat juga mempengaruhi $\mathrm{IMT}^{22}$ Penelitian ini menunjukkan bahwa tidak ada hubungan antara IMT dengan nilai lemak viseral hal ini dapat disebabkan karena keterbatan dalam jumlah sampel penelitian.sampel penelitian diambil secara accidental dalam waktu 2 bulan sehingga hasil penelitian ini tidak dapat digeneralisasikan.

Usia sel/usia biologis adalah usia dari sel-sel tubuh seseorang sehingga kita dapat melihat penampilan seseorang (muda/tua). Usia sel seseorang bisa saja tidak sama dengan usia kronologisnya (usia berdasarkan tanggal lahir). Faktorfaktor yang mempengaruhi usia sel antara lain stress, bahan kimia dari luar tubuh, kurang tidur, pola hidup tidak sehat. Usia sel/biologis juga dapat menjadi penentu dalam menilai kesehatan seseorang yang lebih baik jika dibandingkan dengan usia kronologis. ${ }^{11}$

Hasil penelitian menunjukkan bahwa distribusi responden berdasarkan usia sel dengan IMT normal diperoleh bahwa ada sebanyak 26 (78.8\%) responden dengan usia sel lebih muda atau dari sama dengan usia kronologisnya dan 2 (22.2\%) responden memiliki usia sel lebih tua dari usia kronologis dengan IMT normal. Pada P value 0.00 maka dapat disimpulkan bahwa ada perbedaan antara IMT normal dan IMT tidak normal terhadap usia sel responden.

Pada penelitian ini didapatkan bahwa $78.8 \%$ responden memiliki usia sel lebih muda atau sama dengan usia kronologisnya. Hal ini dapat terjadi karena penelitian ini dilakukan pada remaja usia 18-24 tahun, usia remaja adalah usia yang masih sangat muda. Hanya remaja yang memiliki lemak viseral tidak normal yang memiliki usia sel lebih tua dari pada usia kronologisnya.

Pernyataan ini sejalan dengan penelitian Djuartina dkk, 2012 bahwa terdapat korelasi yang kuat antara usia biologis dan IMT ( $p=0.012)$, yang terdapat dalam penelitian yang berjudul Faktor yang menyebabkan perbedaan usia biologis dan usia kronologis pada lansia. ${ }^{5}$

Namun tidak sejalan dengan penelitian Sofa tentang Kejadian obesitas, Obesitas Sentral \& Kelebihan LemakViseral pada lansia Wanita didapatkan hasil bahwa tidak ada hubungan antara lemak viseral dan usia dengan $\mathrm{P}=0.163 .{ }^{18}$

\section{SIMPULAN DAN REKOMENDASI}

Tidak ada perbedaan yang signifikan antara IMT, BMR, dan lemak viseral pada kelompok remaja, namun terdapat perbedaan yang signifikan antara IMT dan usia sel pada kelompok remaja.

Rekomendasi berdasarkan hasil penelitian di dapatkan bahwa IMT, BMR dan lemak viseral pada remaja yang overweight dan obesitas atau memiliki usia sel lebih tua dari usia kronologisnya maka hal tersebut dapat dijadikan modifikasi perilaku dan gaya hidup sehat sebagai skrining pada remaja overweight, obesitas dan usia sel lebih tua dari usia kronologisnya.

\section{DAFTAR PUSTAKA}

1. Aulia, R. Hubungan Indeks Massa Tubuh dan Aktivitas Fisik 
Terhadap Massa Lemak Viseral

2012

dan Massa Lemak Total Pada

Mahasiswa Universitas

Bengkulu Tahun 2016. 2016;

2. Auliyah A. Hubungan Indeks Massa Tubuh, Persen Lemak Tubuh, Aktivitas Fisik dan Faktor Lainnya dengan Obesitas Sentral pada PegawaiSatlantas dan Sumda di Polresta Depok Tahun 2012. Universitas Indonesia. 2012;

3. Azis N, Fatmah. Level Lemak Viseral sebagai Faktor Dominan terhadap Nilai Lingkar Pinggang pada Petugas Satpam Laki-Laki Universitas Indonesia Tahun 2014. 2014;

4. Cheng HL, Amatoury $\mathrm{M}$, Steinbeck K. Energy expenditure and intake during puberty in healthy nonobese adolescents: $A$ systematic review. Am J Clin Nutr. 2016;104(4):1061-74.

5. Daryanti MS. Hubungan Kebiasaan Makan Dengan Indeks Massa Tubuh Pada Mahasiswi Tingkat Satu Program Studi Bidan Pendidik Di Universitas 'Aisyiyah Yogyakarta. J Kebidanan. 2018;7(1):7.

6. Djuartina, Tena., Sasmita, Poppy Kristina., Mulya Anthyke Efrita. Faktor Yang menyebebkan Perbedaan Usia Biologis Dengan Usia Kronologis Pada Lansia. Prosiding Pertemuan IImiah Nasional Perhimpunan Ahli Anatomi Indonesia : Anatomy for Better Quality of Life, Fakultas Kedokteran Universitas Udayana, Denpasar-Bali. Tahun

11. Manula $P$, Jenis $T$, Suhu $W$, Dan L, Dindng W, Ruang $P$, et al. Miranda nova 11540168715. 1992;15-68.

12. Marsetyo \& Kartasapoetra. IImu Gizi (Korelasi Gizi, Kesehatan dan Produktivitas Kerja. Rineka Cipta: Jakarta. 1991

13. Nafilah N, Fitranti DY. Hubungan Indeks Massa Tubuh (Imt), Persen Lemak Tubuh, Asupan Zat Gizi, Dan Aktivitas Fisik Dengan Kepadatan Tulang Pada Remaja Putri. J Nutr Coll. 2014;3(4):680-8.

14. Pradana A. ( Studi Kasus Pada Mahasiswa Kedokteran Undip ) 
JURNAL MEDIA MEDIKA MUDA. J Media Med Muda. 2014;3(1):615

15. SARI RI. Faktor-Faktor Yang Berhubungan Dengan Status Gizi Remaja Usia 12-15 Tahun Di Indonesia Tahun 2007. 2012;2007:10-35.

16. Setiowati A. Hubungan Indeks Massa Tubuh, Persen Lemak Tubuh, Asupan Zat Gizi dengan Kekuatan Otot. Media IImu Keolahragaan Indones. 2014;4(1).

17. Siswianti YA. Hubungan berat badan, persen lemak tubuh, status gizi $(\mathrm{imt}) / \mathrm{u}$, umur menarche ibu dengan umur menarche pada siswi di SDN Cikaret 01 Cibinong Kabupaten Bogor tahun 2012. Fkm Ui. 2012;29-37.

18. Sofa IM. Kejadian Obesitas, Obesitas Sentral, dan Kelebihan Lemak Viseral pada Lansia Wanita. Amerta Nutr. 2018;2(3):228.

19. Suryana S, Fitri Y. Hubungan Aktivitas Fisik dengan IMT dan Komposisi Lemak Tubuh. AcTion Aceh Nutr J. 2017;2(2):114.
20. Wahyuni $Y$, Dewi $R$, Utami TP. Upaya Preventif Penyakit Degeneratif Melalui Pemeriksaan Lemak Viseral Masyarakat Di Wilayah Pesantren Asshiddiqiyah .... EsaunggulAcld [Internet]. 2017; Available from: https://www.esaunggul.ac.id/wp -content/uploads/2018/02/17.Upaya-Preventif-PenyakitDegeneratif-MelaluiPemeriksaan-Lemak-ViseralMasyarakat-Di-WilayahPesantren-AsshiddiqiyahJakarta-Barat-2017.pdf

21. Wijaya GBR, Muliarta IM, Permana P. Faktor-faktor yang berpengaruh pada Indeks Massa Tubuh (IMT) pada anak Sekolah Menengah Atas (SMA) di Kecamatan Buleleng, Bali, Indonesia tahun 2016. Intisari Sains Medis. 2020;11(1):223.

22. Yuli Hartyaningtyas G. FaktorFaktor Yang Mempengaruhi Indeks Massa Tubuh (IMT) Pada Siswa SMA Marsudirini Bekasi Tahun 2013. J Gizi Indones. 2013;3(1):98-105. 
Jurnal Untuk Masyarakat Sehat (JUKMAS)

http://ejournal.urindo.ac.id/index.php/jukmas 